\title{
The Peruvian Military Government: The Problems of Popular Participation
}

\section{by David Scott Palmer and Jorge Rodriguez Beruff}

The nationalist and reformist policies of the Peruvian Military Government have elicited great interest in the developing world. The Peruvian Military have increasingly followed a more autonomous foreign policy vis-a-vis the United States, of which the more dramatic examples are the International Petroleum Company (IPC) controversy and the 200 miles territorial waters dispute. Internally several reformist measures have affected both certain local power groups and some powerful foreign interests.

Among these measures are the Agrarian Reform Law, the reorganization of the banking system, the General Law of Industry, the Mining Law, the Telecommunications Law, and the forthcoming Educational Reform Law. Some implications of these policies of economic and social change have been discussed elsewhere by Anibal Quijano. ${ }^{1}$ The Military are committed to changing not only the 'traditional' economy and society, supposedly in the direction of a more egalitarian distribution of rewards, but also a power structure which they consider a natural corollary of 'traditional' society. Thus, one of their stated goals is the promotion of the political participation (also known as social mobilization and power transference) of the 'historically marginal majority'. This article will center on the strategic role played by the State bureaucracy in this respect as well as on the model of a political system which seems to be emerging from the practice and the ideological postulates of the military government.

David Scott Palmer, Visiting Professor in the Program of Social Sciences of the Catholic University of Peru, and Ph.D. candidate in Government at Cornell University. Jorge Rodriguez Beruff, Graduate Student of the University of York, presently doing research on the ideology of the Military in Peru.

1 "Nationalism and Capitalism in Peru", Monthly Review, JulyAugust 1971. 
The Armed Forces intervened early in the $1960^{\prime} \mathrm{s}$ in order to place President Belaunde and his Accion Popular party in power. Despite this military backing, Belaunde was unable to overcome fierce Congressional opposition from a coalition of the APRA and the conservative right. He thus failed to satisfy the demands for reform made by those social groups which had been historically excluded from the political system but whose expectations had been raised by The Belaunde Program.

In a study on the guerrilla movement of 1965, the military diagnosed, not incorrectly, that Peru had entered a period of 'latent subversion'. The economic crisis of 1967 and the worsening of the inflationary process, the first in 15 years, further reduced public confidence in the capacity of existing institutions either to effect needed reforms or to ensure a degree of economic stability. The steps taken to face the crisis were far from popular. The coalition of all the main political forces under a conservative platform (known as the superconvivencia) in the last 100 days of the Belaunde Government and a $40 \%$ devaluation of the currency only accelerated the decline in legitimacy of the existing institutions. The almost unbelievable incapacity of the Government to resolve the IPC issue, which had figured prominently in Belaunde's original reform platform, confirmed to the people that they had very little stake in maintaining this 'constitutional' government.

The Military: The Rise of a Reformist Ideology

The decline in public confidence in Belaunde was paralleled by a decline in the support offered to him by the Military. The out look of the Military themselves had undergone profound changes. These changes placed them increasingly to the left of APRA, their traditional foe, which had, since 1956, clearly adopted conservative positions to obtain the favour of the United. States and the dominant social groups.

This reorientation of military thinking had first appeared in the form of a concern about the relationship between the 'national potential' and security and, therefore, of the need for industrialization and economic growth. The academic elite of the Centro de Altos Estudios Militares (CAEM) played a central role in the formulation and popularization of these ideas among the officer corps during the fifties.

1 Alianza Popular Revolucionaria Americana. 
After the Cuban Revolution, the attention of the military shifted to internal security, reinforced by French and American military doctrines of civic action and antisubversive war, and the need to reform in order to stem revolutionary activity. The Military were indeed aware of and worried about the growing mobilization of popular groups. The rural movement led by Hugo $\mathrm{Blanco}$, the establishment of three guerrilla fronts, the increase in unrest among the urban working class and middle class students showed them that a repetition of the Cuban 'catastrophe' might be possible in Peru. Thus within the military intelligence machine which was strengthened to meet the crisis, a group of officers were reaching the same conclusions as the academic elite of CAEM: the causes of revolt lay in the structure of Peruvian society; and repression was not a durable answer to insurgence. Reform was necessary. As these ideas were becoming dominant within the officer corps, Belaunde was proving incapable of carrying out the promised changes. For the Military the problem then became, as a prominent General has put it, "not whether to intervene, but when". The IPC scandal settled that problem.

\section{The Military in Power}

It is clear that the military government has benefited greatly from the weakness of the regime that preceded it and the decay of the old mechanisms of participation. It has been able to formulate and implement policies without giving serious consideration to demands coming from the old power institutions, especially the political parties. In Peru, unlike other Latin American countries such as Argentina, Chile and Brazil, a mass-based populist movement has never reached the top seats of political power. In addition, the country has never experienced a fundamental social or economic reform.

For these reasons the present military government has had a great deal of 'political space' in which to manoeuvre. It has not had to confront serious opposition at the national level, and by pursuing a programme of reforms it has been able to claim legitimacy for its rather long stay in power. However, the lack of communication between the government and the groups it is trying to benefit may create conflicts precisely with those groups which, it hopes, will constitute its basic civilian support.

ro discuss the present mechanisms of participation it is necessary to distinguish between participation at the center 
and the periphery (i.e. at the national or local/sectoral levels). We must also note the difference between participation in the posing of demands and participation in the implementation of decisions. These distinctions are important to the understanding of present politics in Peru. They raise the issue of whether it is possible to apply uncritically an "input-output" model when the bureaucracy is far from the Weberian 'ideal' and far from politically neutral.

Conflict at the Center and the Bureaucratic Representation of Interests

Anibal Quijano has characterized the power structure that emerged after the 1968 coup as a military-bureaucratic coalition, emphasizing a community of interest between the dominant reformist group of officers and the technocratically oriented bureaucrats in the higher echelons of public administration. We consider it more fruitful, however, to look at the cleavages and conflicts within the bureaucracy and their relation to the problem of participation. It is true that bureaucratic conflict occurs within certain limits: those dictated by the 'permanent interests' of the bureaucracy itself. But, as we will illustrate, conflict does occur (it may have been greatly magnified after the coup) and affects the formation and implementation of policy.

The legitimacy of traditional mechanisms of participation (i.e. parties and pressure groups), as we have seen, had suffered severely during the Belaunde government. After the coup they proved incapable of dealing with the ruling military elite. The politically active groups, therefore, unable to make their demands heard through traditional channels, sought to control or influence the bureaucracy. This produced a shift in the area of conflict and increased the strategic importance of public administration.

There are two factors that contribute, in the case of the Peruvian bureaucracy, to the politicalization of its members and to the intensification of internal conflicts. First, access to it was based in the past on political clientelism, so it resembles more an agglomeration of various superimposed 'ideological' groups (Pradista, Belaundista, Aprista) than a homogeneous 'modern' bureaucracy manned by career functionaries. Secondly, the Military are 
torn between the conflicting goals of obtaining a high degree of ideological homogeneity within the ruling 'team' and of maintaining the institutional unity of the Armed Forces. The result has been a compromise: there have been purges of some right wing and some left wing ministers, yet a degree of pluralism at the level of the Council of Ministers has been maintained. The military personnel assigned to the Ministries reflect this diversity of political persuasions and soon identify their ideological reference groups within the civilian bureaucracy.

The different bureaucratic groups seek to legitimize their positions by identifying with those sectors of the ruling 'team' and of the military personnel assigned to the Ministries who are closest to them ideologically. The form in which directives from the center (Presidency, Council of Ministers) are interpreted and implemented is determined by the coalitions and power relations of the various factions at the ministerial level. The ties between competing groups that sometimes occur result in the immobilization of the administration which is perceived higher up either as 'lack of morality' (corruption) or as open sabotage by opposition elements.

Although conflict within the bureaucracy may sometimes not be conciously political, its results are clearly so, since the form in which the decisions are implemented or simply not put into effect is of political concern to the groups outside the State structure who are affected by them. These groups do perceive the political implications of the conflict and try to benefit from it, for example, by putting pressure on those ministries most directly related to their interest. The enterpreneurial and working class groups aim at controlling or influencing the Labour Ministry; the Church, the private schools and the teachers put pressure on the Ministry of Education, and so on.

It should be noted that the Peruvian State structure is highly centralized and that not all politically active groups have access to the middle or higher levels of the Zineno bureaucracy. Their exclusion from this form of struggle may stem either from geographical reasons or from their relative lack of weight vis-a-vis other nationally organised groups. 
The relationship of the average citizen to the political system under military government may be interpreted in terms of a 'corporatist model'. This model has three major components. The first is the ability of the citizen to express and resolve daily concerns through participation in functional groupings, such as neighbourhood committees, industrial communities, agricultural cooperatives and peasant communities. The second is constituted by the opportunities available to influence the way in which decisions made at the center are implemented. This can be accomplished either by working through the 'normal channels' of the local contact points of government agencies or by the use of 'extraordinary escape mechanisms' such as clientelism, delegations, marches, strikes and land invasions, to influence individuals and/or agencies higher up in the government hierarchy. The third component of the model of military corporatism is the centralization of control and the asymetrical process of 'government-down' mechanisms.

Participation by the citizen does indeed take place, but almost exclusively within the 'government-down', or 'output' process. Local concerns are worked out within local participation units. When citizens wish to affect the way in which decisions are made at the center or implemented through the bureaucracy, their leaders work through the local or sectoral contact points of government. Insofar as local contact points prove unresponsive, local particiaption units express their concerns through 'extraordinary' mechanisms. These mechanisms do not ordinarily include traditional power organizations such as pressure groups or political parties. This is due to the disrepute into which the normal input mechanisms fell during the years preceeding the most recent coup, and the conscious attempt by the military government since then to eliminate their influence as institutional input groups. To quote one of many official references, "The only thing political parties could do well was what they did badly". Such organization among local units which does take place occurs within functional areas. The official view is that this serves to protect the members from the 'corrupting' influence of outside entities such as parties, and helps them to coordinate the presentation of their concerns at local contact points.

These trends point to the rise of a model of politics significantly different from that dominant before 1968. A number of cases suggest, however, the difficulties which the 
military government of Peru is experiencing in its attempt to make operative the corporatist model of politics.

Friction within the Bureaucratic 'Transmission Belts'

One example is the way in which decisions are made in the upper bureaucracy of the central government. This process reveals the degree to which lingering resistance to change orlents large segments of the entrenched bureaucracy. A particularly suggestive example is to be found within the Ministry of Education, where an alliance between the Vice-Minister (a Colonel) and entrenched bureaucrats has succeeded in dominating a group of CAEM - trained officers from the influential Ministerial Advisory Council. These officers, who were working for a 'radical' educational reform have been routinely rotated and replaced by a less experienced group. The Educational Reform Law was passed in March 1972. It is being implemented by precisely that sector of the bureaucracy least interested in innovation or in changing the established routine and priveleges.

Failure of the 'Local Contact Points' of Government

A. The Huanta Massacre, 1969

A second case refers to the employment of 'escape mechanisms' after successive efforts to influence local contact points early in the military government failed. This is the protest in June 1969 in the gierra provinces of Huanta and Ayacucho over the promulgation and attempted implementation of a law which would have ended free schooling for any students of secondary school who failed a course (The law provided for a payment of about fl per month per course failed. Minimum wage in the province is about 30 p per day). A temporary alliance of students, parents, and peasants succeeded in forcing the central government to revoke the law, but only after taking over city of Huanta and provoking the national guard assault force into killing 18 and wounding 100 of them.

It was apparent in this case that the government contact points at the local level - school directors, the police, and the sub-prefect - failed to give the central government an accurate assessment regarding the strength of mass opposition to the law. As a result, central government did not fully perceive the needs of that segment of the population (the lower classes) which would have been the most adversely affected by 
the measure. Moreover, the local contact points in this example, had neither the power to change the law, nor, from all appearances, the skill to reconcile citizen opposition. As a result, citizens were forced to resort to extreme measures to demonstrate their hostility to the new law. The first response of the central government was to send in troops to settle the matter by force. The magnitude of the miscalculation became clear after a large number of people had been killed and the nation made dramatically aware of the depth of the problem. On June 24, 1969, the same day as the Agrarian Reform Law was decreed (which may indicate where national government's attention had been focussed during the build-up of the crisis in Huanta), the obnoxious provisions of the education law were repealed.

\section{B. The Pamplona Invasion, 1971}

A more recent example of the ambivalence of the military government in practice toward the problem of mass participation in the political process is the massive urban land invasion of Pamplona, on May Day, 1971. While the organized invasion of vacant 1 and around Lima has become a common method for the urban poor to get their own house lot free of charge, the Pamplona invasion was one of the largest (an estimated 10,000 families before it was over), and the first since the Revolutionary Military Government took office.

Only after clandestine attempts by the government to remove the invaders by force in the pre-dawn darkness of three successive mornings had failed, and after one citizen had been killed (5l national police were wounded by sticks and stones), were steps taken to recognise the new reality. The normal work of the Ministry of Housing and the National Office for 'Young Towns' (as the 300-odd squatter settlements have come to be called) was completely reoriented. A new 'Young Town', Villa El Salvador, was created in short order, and the thous ands of men, women, and children in Pamplona were registered and then moved there by army trucks. The government installed basic services such as water, electricity, paved streets, and schools within a few months. Government agency 'contact points' with the Young Towns grew rapidly in number. From the point of view of the citizens, one of the main reasons for the invasion in the first place was that there was only one poorly placed office of the National Young Towns Agency to service the concerns of about a million residents.

Most previous invasions have also succeeded in obtaining official government recognition, but only after years of 
pressure and haggling. Even though the official response in this case was hasty, ad hoc, and chaotic, the demands of the citizens through these 'extraordinary channels' were met. Critics noted that one reason for the rapid response was the proximity of the original invasion site to one of the most wealthy suburbs of Lima. Another was the desire to avoid alienating the progressive wing of the Catholic Church, intimately involved with work in the Young Towns in general and Pamplona in particular. Finally, there is some evidence of attempts within the highest levels of the military itself to utilize the invasion as a springboard for a realignment of power towards the right. This at tempt failed, of course, and the citizens were the principal beneficiaries. Yet both the process by which they became beneficiaries and the reasons for it suggest a continued inability by the Military Government to keep communication channels between citizen and government at the lower levels sufficiently open to permit the routine channelling and resolution of concerns from below.

Much of this difficulty arises from the way in which the military has defined its 'revolution'. They are attempting to achieve the most difficult of objectives - to transform Peruvian society without wholesale destruction of existing institutions and widespread violence. There are any number of manifestations of their attempts to reach this objective. They want to preserve their attractiveness for foreign investment while eliminating the worst abuses (and abusers) of the past. They want to reduce their external dependence by diversifying it. They want to maintain incentives for domestic private enterprise while increasing the share of profits and of management responsibilities accruing to the workers. They want to dynamize the public sector without drastic changes in the bureaucracy entrusted with the implementation of public policy. All this is to be accomplished in a context of scarce domestic resources and continued reliance on foreign capital. Even if all their policy initiatives were enlightened, and if they met with immediate success in achieving their objectives, which they have not, the abuses of the past would continue to exist for some time side by side with these initiatives of the present. As far as popular participation in the decision-making process is concerned, the most difficult stumbling block lies in the preservation of government bureaucracy and of continued limits on that effective expression of demands at either the local or the national levels. 
Another important reason for the difficulties facing the present reformist government has to do with the striking contrast between their stated goal of local control (auto-gestion or self-management) and more than 400 years of history. The structures of government of both the Spanish Empire and Republican Peru after 1825 were extremely centralized in nature. This characteristic has been preserved in present-day institutions, whose resistance to change is enhanced by the fact that changes are being initiated by a military institution which is itself extremely centralized and hierarchical.

\section{Inadequacy of Government 'Local Contact Points'}

A few observations regarding the operation of the 'local contact points' of government will illustrate the tension between rhetoric and reality, objectives and current practice. The government's agrarian reform program has some 300 technicians on the front lines at present, known as sectoristas. They are assigned to small geographical areas affected by the agrarian reform, and they have responsibility for its day-to-day implementation. In terms of the objectives of this Revolutionary Military Government, their role is crucial.

In practice, however, these sectoristas are unable, for the most part, to carry out the tasks assigned to them. They are paid less for their efforts than any other government employee group working for the agrarian reform except day labourers and some secretaries: about $£ 25$ to 135 per month. The level of education required for these posts is two years' study beyond secondary school in practical agriculture. They have been trained to solve the technical problems of agriculture rather than the organizational problems of reordering rural society, and their occupational role under the agrarian reform is normally defined in these terms. Any organizational skills which the sectorista brings to bear in his relations with the peasants depend largely on the personality of the individual. In many parts of the country they receive little institutional support; lacking their own transportation, for example, they must often wait for days or weeks for vital materials or even, in extreme cases, for a lift back to their sector of operations. The official practice of assigning personnel to areas other than that in which they were born and raised often deprives the agrarian reform of 'contact points' fluent in the language of the peasants with whom they work. When one or another of the sectoristas overcomes these multiple obstacles and does an effective job in the field for a few 
months, he is immediately rewarded by an office job at the regional headquarters. Until these institutional obstacles are removed, the application of the citizen-participation model to the rural sector will continue to be fraught with difficulties.

\section{SINAMOS and the Official Solution}

Needless to say, the government is quite aware of the magnitude of the problem of bringing about an effective channeling of popular participation. They feel that they have found an answer in the newly created (June, 1971; to be operative between January and April, 1972) "National System of Support for Social Mobilization" (SINAMOS). The full name is an awkward mouthful; the acronym is not (it means, "without masters"). The proclaimed objective of this agency is to stimulate participation without controlling it. According to SINAMOS director General Leonidas Rodríguez,

".... we want to stimulate and make possible the creation of autonomous organizations through which our people may increasingly participate in the solution of the social, cultural, economic, political and instiutional problems that affect their daily lives as members of society".

At the same time the aim is to coordinate the various government agencies which deal with social mobilization in one form or another. Under the umbrella of SINAMOS, all such agencies as the National Development Fund, the provincial development corporations, Rural and Urban Social Promotion, the National Cooperative and Community Development offices, the Peasant Communities and Peasant Organizations Offices, and the Agrarian Reform Promotion Office. However, the actual commitment to participation has been somewhat ambiguous. SINAMOS has coordinated efforts to bring out the crowds at public gatherings for speeches by the President and Ministers. They also appear to be working to stimulate the people to organize themselves in neighbourhood committees, or cooperatives, or federations in order to contribute to the creation and maintenance of a viable infrastructure of popular participation. ${ }^{1}$ To quote General Rodríguez again:

"... so that the Peruvian citizens may have the opportunity of participating in posing and solving problems

SINAMOS has received a mandate to reorganize participation along more egalitarian lines in the agricultural production cooperatives of the North Coast sugar belt. 
related to the multiple services and needs of their neighbourhoods, their places of work, the schools where their children study, their function in the economy as workers of different types, as inhabitants of a particular territorial area and as members of a national collectivity that confronts problems of extremely varied nature and significance".

As we have pointed out, however, this effort to stimulate local units of participation runs counter to the country's long experience and present reality. It is also being carried out by a leadership which lacks confidence in the ability of the common man to make decisions for himself. To what degree national history and popular perceptions can be reversed remains to be seen. Many observers, ourselves included, feel that the tension between the rhetoric of the revolutionary government and its inability, in spite of the best of intentions, to fulfill completely the expectations raised, will exacerbate tensions in the middle term. If adequate mechanisms of participation are not firmly established in the few years during which the present government enjoys relatively high legitimacy, popular dissatisfaction will be channelled increasingly through extra-institutional mechanisms. The efforts expended in arousing popular expectations and in teaching the people how to organize without giving them effective voice in decisions would then begin to haunt the ruling élite, and could lead to dramatic changes in the present course of reform in Peru.

Lima, PERU

January - February 1972 